\title{
Australia-US Alliance and Strategic Geometry in the Indo-Pacific Region: An Evaluation
}

\author{
Ashok Sharma*
}

\section{Abstract}

The $21^{\text {st }}$ Century is witnessing a significant change in the strategic landscape. The US hegemonic power that provided the stability for almost seven decades is in relative decline. Over the past decade, amidst the receding hegemonic status of the US, nation states, and especially the rising powers, are reformulating their foreign policy to reposition themselves in the strategic transformation by enhancing their defence capabilities, asserting militarily and forming countervailing alliances. Countries such as China, Russia, France and Germany, have challenged U.S. unilateralism in the United Nations and other forums such as NATO, whenever their interests have not converged with the United States. This receding trend of hegemonic influence is visible in the Kosovo crisis, Iraq war, and recently in the Ukrainian and Syrian crisis.

Keywords: US-Australia relations, Indo-Pacific region, strategic relations, Defence White Papers, FONOPS

Adjunct Faculty, The University of New South Wales, Canberra, Australian Defence Force Academy, and Deputy Chair, New Zealand Institute of International Affairs, Auckland; dr.akssharma@gmail.com 


\section{Introduction}

The era of western ascendancy since 1750 and of US ascendancy since 1945, known as Pax Americana, is coming to an end. By 2030 Asia will be bigger in economic size and strategic weight than Europe and the United States combined, but the United States will remain the first among equals, with the EU, China, India and Japan as the leading contenders to be counted among the equals. Asia's emergence as the fastest growing economic region and changing geopolitics, driven by the re-emergence of China and of India as major nodes of global activity, and the relative U.S. decline from dominance have given rise to new strategic alliances between the region's major players. Australia too is repositioning itself in this shifting global order (Thakur 2013; NIC 2012).

However, the challenge to the US hegemonic power is most visible in the Indo-Pacific /Asia-Pacific region (Indo-Pacific and AsiaPacific are used here interchangeable for the same geo-political region) where the emerging and re-emerging great powers are expanding their sphere of influence. On the one hand, the stability provided by U.S. pre-eminence in the Asia-Pacific region is being challenged by the economically powerful and militarily assertive China; on the other hand the rising economic and military profile of India and Japan is witnessing a new set of strategic alliances and partnerships to maintain the stability in the region.

Amidst the uncertain strategic scenario at the global and regional level, Australia is today faced with challenge of uncertainty about the US pre-eminence and commitment to the Asia-Pacific region amidst the alarming rate of the Chinese military assertiveness and North Korean display of its nuclear and missile capability to threaten the US and its allies with a possible nuclear attack. The US-China competitive relationship and the trade flows through the Asia-Pacific region are bringing new strategic challenge for Australia.

What emerges from the above is an assessment of Australia's alliance with the United States in the Asia-Pacific/Indo-Pacific region. The article scans the ongoing debate in Australia on the continuation of the Australia-US security alliance amidst the emerging strategic geometry in the Asia-Pacific region. To capture 
the debate this article uses the periodic Australian Government documents which have been released in the form of Defence White Papers (DWP) and National Security Papers, and the recent arguments in the Australian political circle. The article observes that to pursue Australia's national interest is increasingly becoming difficult given the competitive geostrategic environment in the Indo-Pacific region. Despite the opposing voices to reassess Australia's relationship with the US, the alliance will remain significant for Australia's security interest. Australia's alliance with the United States that has been tested by time and marked by the mutual confidence and trust, coordination and interoperability. The relationship is deeply enrooted in the values and principles of democracy, and grounded in the geostrategic realities.

Divided into five sections, the article deals with the traditional ties between Australia and the US; debates surrounding Australia's alliance with the US; Trump's flip flop policy on containing China's growing military build-up; Chinese Growing Assertiveness in the Asia-Pacific region and tensions on competing claims over the South China Sea; and Australia-US alliance is inevitability amidst the strategic realities; and a conclusion.

\section{Traditional Bonhomie: Australia-US Security Alliance}

Historically, Australia and the United States have shared a strong security alliance, formally cemented in 1951 under the Australia, New Zealand, United States Security Treaty (ANZUS). Since then, Australia has joined the U.S. military efforts when necessary. The U.S.-Australia security alliance continues to enjoy domestic support both in Washington and in Canberra - contributing to the prolonged economic and security partnership between the two countries (Sharma 2016). Over a period of time, both the nations' armed forces have developed mutual confidence and interoperability.

Australia's alliance with the United States has survived for a long time. Australia's endorsement and acceptance of its alliance with the US is manifested in various Australian Government documents, including Australia's Defence White Papers. Australians have normally assumed that their defence entails the domination of the 
Western Pacific by an Anglo-Saxon maritime power and have given priority to supporting their ally's primacy.

But over the past decade, the concern about the uncertain strategic scenario because of the economic rise of China and its assertive military posture, and the improbability on sustainability of the US hegemonic power in ensuring the stability in Asia-Pacific region have figured prominently in the Australian foreign policy debate. The 2009 DWP, developed in the midst of the global recession, recognised the unfolding security structures of the wider AsiaPacific region and the need for a firm geo-strategic stand in its neighbourhood region in terms of the force structure drivers. DWP notes that since the beginning of the $21^{\text {st }}$ Century, the biggest transformation has been the rise of China, the emergence of India and the receding trend in the pre-eminence of the United States as the hegemon in the so-called unipolar moment for almost twodecade-long period in which the superiority of Australia's main ally was unchallenged. Though it acknowledges the emergence of other great powers-"China, India, Russia, Japan and the European Union", the DWP envisions that the US will remain the most powerful and influential strategic actor over the period to 2030 politically, economically and militarily. Its strategic primacy will assist in the maintenance of a stable global strategic environment. At the same time, it states China's strategic posture as ambivalent (DWP 2009, 30-32).

In the 2012 White Paper (WP), Prime Minister Julia Gillard acknowledged that Australia's geography is its destiny: "The Asian century is an Australian opportunity" (WP, 2012). The 2012 WP titled "Australia in the Asian Century" foresees Australia as promoting cooperative arrangements among nations in the region as the economic and strategic landscape shifts. The DWP supports China's participation in the region's strategic, political, and economic development. It talks about the importance of an emerging strategic scenario because of the rise of China and the resulting impact on its regional and global interests, as well as those of its neighbours; India's increasing re-engagement in East Asia; and the United States Re-Balancing Act in the Asia-pacific region. The DWP supports the continuation of Australia's alliance 
with the United States, and its powerful and consistent presence in the region for its resulting stability, security and peace (WP, 2012).

The 2012 DWP viewpoint is essentially echoed in the national security outlook in the "2013 Strong and Secure: A Strategy for Australia's National Security". Protecting Australia's border integrity, deterring attacks on Australia, and protecting and promoting Australia's interests in a secured international environment; the document places emphasis on the trilateral security alliance of Australia, the US, and Japan and the AustraliaUnited States Alliance (Australian Government, 2013). The 2016 DWP presents a strong strategic argument for Australia's future defence based on seizing opportunities while managing strategic challenges. Significant emphasis is on the Australian Government's strategy to continue to strengthen its alliance with the United States (DWP, 2016).

Almost all the Australian DWPs emphasise the significance of Australia-US alliance which has been strongly backed by the Australian Government. The astounding scale and pace of change, led by the growing economic weight which is translating into strategic weight, is transformative for the world and the Asiapacific region. This is gradually posing challenge to Australia's strategic posture in an intense and competitive geostrategic environment.

\section{Debating Australia's Alliance with the US}

Since the 1970s, China's massive push towards modernisation, urbanisation, manufacturing, and infrastructure development produced a demand for resources, energy, and raw materials. Australia was well placed to meet a lot of this demand, and it was a ready market for Chinese manufactured goods (Holmes, 2013). As a result, China became Australia's largest trading partner in the late 2007, and in 2009 Australia's largest export market with more than $\$ 150$ bilateral trade (Australian Embassy in China). The AustraliaChina economic bonhomie will continue to expand. However, the Chinese military build-up is creating uneasiness for the historicallyresilient Australia-U.S. security alliance. The evolving strategic geometry in the Asia-Pacific region can potentially affect Australia more than any other security problem in the world. Australia is 
faced with the challenge of maintaining its economic ties with China and its security alliance with the United States. Despite the growing significance of the Asia-Pacific region, Australian policymakers had not to face the challenge of choosing between its military and economic partner, or between European history and Asian topography. This has continued for a long time. Even during the era of Prime Minister John Howard (1996-2007), the dominant intonation was that Australia did not have to choose between European history and Asian geography.

Over the past decade, the Australian foreign and security policy debate has revolved around Australia's alliance with the United States. The questions have been raised regarding the continuity of the Australia-US security alliance. The clamour for a more independent foreign policy has come from the influential voices in the past. This includes the former opposition leader John Hewson, who demands an immediate parliamentary debate on future diplomatic and military strategic choices to pursue Australia's national interest in the current security threat environment (Malone 2017). The most vocal opponent of the alliance is the former Australian Prime Minister, Malcolm Frazer, who advocates for a reevaluation of Australia's commitment to the US alliance. In his book Dangerous Allies, published in 2014, Frazer questions the continuity of the alliance, as the Australian economic interest lies with China and the broader Asia Pacific region. He points to the cost that Australia is paying for the alliance. He argues that, as a part of an American network, Australia is a compliant partner and a strategic captive of the US, and considered merely as a surrogate voice of America and therefore exerts no true influence (Frazer). His views were summarised by former Labor foreign minister Gareth Evans as "the only aggression for which we are likely to need American defence will be that prompted by the alliance itself" (Malone, 2017). The critics of Australia-US ties see the alliance as undermining Australia's weight in Asia.

Paul Keating, the former Prime Minister from the Labour Party, urges a reconsideration of Australia's alliance with US, and cautions Australia on getting into a confrontational situation in the evolving strategic rivalry between Washington and Beijing. Unlike Fraser's extreme position of outright rejection of alliance and 
cutting off ties with the US in total to avoid Australia's involvement in the war, Keating takes a more moderate view and urges the Australian government to make efforts to shape the outcome of US-Sino rivalry to avoid war.

However, these individuals who are challenging the sanctity of Australia's relationship with the United States are no longer in power or serving in the government. They are not responsible for their words or actions. It is easy for former leaders to question Australia's relationship with the US. Their critics say that this is partly because staffs are rewarded for backing the alliance, and those opposing the alliance get no promotion and no attractive postings in the departments.

Recently the debate has been focused on whether Australia should join the US-led Freedom of Navigation Operation Program (FONOP) in the South China Sea. The strongest advocacy for the joining of the US-led efforts to stop Chinese expansion has come from the former Prime Minister John Howard. Expressing his concern on China's unabated expansionism and violation of the international rules-based order, Howard said "I think this country should be ready at some point, if circumstances are appropriate, and that would be a matter of judgment of the government at the time, to be involved in freedom-of-navigation operations. I think we should be willing to be part of that. I can't think of any alternative to it" (Riordan, 2017). Australian defence experts are divided over the merits of Australian involvement. Former Defence Force Chief, Sir Angus Houston, has said it would not be a good idea as it would provoke a military response, while former Defence Department head Dennis Richardson said it could be a good idea if done in a non-provocative way. Currently, in the Coalition Government some including Tony Abbott, Kevin Andrews and Eric Abetz have advocated for confronting China (Riordan, 2017). But the Turnbull Government is hesitant as reflected in Foreign Minister Julie Bishop's statement that Australia is yet to commit to sailing that close to the islands, which would escalate tensions. The poor handling of Australia's positioning in the US-China competition may threaten to drive a wedge between the United States and Australia, and potentially undermine Australian security and its foreign policy (Fontaine, 2016). 
The receding hegemonic influence of the US over the past decade, and more recently, the uncertainty of the US President Donald Trump's flip-flop policy on the Chinese militarily assertive posture in the South China Sea have flared the debate and question the US as reliable security provider in the region. The allies are finding it hard to reconcile their national interests with that of 'America First and American Interests' under Trump presidency. Critics point out that Australia is being seen as Trump's man in the Asia Pacific which enhances Australia's security threat and makes it vulnerable to the countries in the region, which are adverse to the US.

\section{Trump's Wavering Policy on China's Military Build-up}

Trump's initial tough talk on the Chinese aggression, both on the economic and military fronts, is now being seen as mellowed down. Trump's inaction on his promise to impose a 45 per cent tariff on Chinese imports, and the Pentagon's decision to turn down Pacific Command's request for US warship patrols in China's proclaimed territorial waters are testimony this concern. Apparently wary of angering Beijing, the US decision to suspend patrols of islands and reefs claimed by China (Malone, 2017). The US allies also have expectations from the US for leadership on a range of demanding political issues. But Trump's erratic stand on the countering Chinese aggression in the South China Sea is becoming concerning for the China wary countries which depended on the US as a security provider in the region. The renewed North Korean nuclear and missile developments have further deviated Trump. The US inability to look beyond North Korea is further questioning the credentials of the US as a formidable power for the maintenance of stability in the region.

Trump's demand from South Korea, an ally for the six decades, for the payment to an antimissile system built by the US to deter North Korea has not gone well with Moon Jae-in, the new president who is pursuing a more appeasing approach with the North Korea. This is likely to further create a drift in the US-South Korea relations (Hernandez, 2017). The US policy of imposing tough sanctions has not been able to stop the North Korean nuclear and missile programme. 
In other parts of Asia-Pacific region, including the Philippines, Taiwan and Vietnam, Trump's policy has created an unease as they are worried that Trump might ease the US counter-balancing strategy to deter China in the region. The delay of arms sale to Taiwan by the US is further being seen as conciliatory stand on Chinese aggression. The Philippines is worried about the United States' wavering approach to challenge China in the South China Sea (Hernandez, 2017). The United States' inability to put a strong resistance to counter China may create a situation in which the countries may look for the option of mending their ties with China and move closer to China (Hernandez, 2017).

On the economic front too, Trump's abhorrence for multilateralism and the US withdrawal from Trans-Pacific Partnership, a trade pact that was expected to have significant benefits for Southeast Asia, further questioned the US commitment to the Asia-Pacific nations. To fill the void and lure the Asia-Pacific nations, China has proposed to double down its investment in the region.

President Trump's delay in settling in the office, the US involvement in the Syrian crisis, and the latest of North Korea's renewed nuclear and missile activity has diverted US attention from the South China Sea and has given ample space for China to manoeuvre its strategic move in the disputed Sea.

Though many analysts view Trump's thinking and style of working as different and believe it's not what it seems, Trump's supporters point out that the US President is aware of these problems and concerns of its allies. But the pressing demand is the North Korean aggressive nuclear posture and belligerent approach towards the US. His impulsive style and willingness to volte-face decades of accepted policy may be strength, particularly in tackling a stubborn leader like Kim Jong-un of North Korea. But his lack of reassurances to Asian allies and his ease towards China have given the impression that Trump's external policy is crossable.

But there has been tough posture form the Trump administration as well. Starting from his election campaign to the statement by the US Secretary of State there has been an indication that the US action will be tough. The US Secretary of State Rex Tillerson statement suggesting that China should be denied access to the islands it 
built, the Trump administration's response has been strong (Forsythe, 2017). Trump's moderate posture on China further gets diluted after his maiden speech at the UN in which he threatened to totally destroy North Korea if it develops nuclear weapon (ABC, 2017). Trump had threatened that the U.S. might end trade with countries that do business with North Korea after Pyongyang's sixth and most powerful nuclear test which it claims was a Hydrogen Bomb. This also set the stage for a possible standoff between the US and China.

Earlier, Trump's moderate posture on China was seen from the security threat that immediately needed the American President's attention. Consequently, the South China Sea was relegated to the backstage because of North Korea's missile tests and nuclearweapons development. Trump was hoping form China a tougher pressure on North Korea on its nuclear and missile programme, and saw more value in winning China's support for his campaign to confront North Korea over its nuclear weapons and ballistic missile programs.

\section{Chinese Growing Assertiveness in the Indo-Pacific Region: Tensions on Competing Claims over the South China Sea}

China economic rise has enabled it to strengthen its military buildup and a greater strategic influence in the Indo-Pacific region. In recent years, China has taken steps toward a greater control over the South China Sea and the Indian Ocean by enhancing its naval capabilities, militarizing islands in the South China Sea, and building the artificial islands and port facilities in the Island nations to mark its presence in the region. To reinforce its claim over the South China Sea, China has erected around 250 islands. The intensity of Chinese military assertiveness in the South China Sea has made it a zone of competing claims. China claims the right to it by pointing to historical maps that prove its ownership of almost the entire sea. But the Chinese claim is disputed by competing claims of the countries such as Indonesia, the Philippines, Malaysia, Brunei, and Vietnam. The South China Sea, a huge stretch of waterways, is rich in oil and gas resources, and more than \$5 trillion dollars' worth of international trade is shipped through it every year. 
China defends its actions in the South China Sea on historical, economic, and security grounds (Coonan, 2016). But, this does not mitigate the wariness of surrounding nations in the Asia-Pacific region. The Chinese assertion in the South China Sea has been meted out with a strong reaction by the previous US administration under President Obama. The US has responded to the Chinese claim over the South China Sea through its FONOPS. In 1979, the FONOP was started by the US government to contest unilateral acts of other states designed to restrict the rights and freedom of the international community. The programme includes both manoeuvres aimed exclusively to challenge maritime claims that the U.S. considers excessive, and operations with other purposes that incidentally challenge territorial claims. The recent freedom of navigation exercise began after the Chinese activities in the South China Sea were taken to the international court by the Philippines Government in 2013 (USNI, 2017). Since October 2015, the US has been doing the freedom of navigation drill udder the incontrovertible norm of freedom of navigation in international seas, as mentioned in the United Nations Convention on the Law of the Sea (UNCLOS). In January 2016, the U.S. missile destroyer USS Curtis Wilbur sailed within $22 \mathrm{~km}$ of Triton Island in the Paracel chain announced in order to challenge the excessive maritime claims by China and other claiming nations in the South China Sea (SBS, 2016). On 10 May 2016, the USS William Lawrence (DDG-110) sailed within 12 nautical miles of Fiery Cross Reef (Harvard Kennedy School), a contested artificial island in the Spratly Island chain.

China is also critical of the US naval operations in the South China Sea. Beijing contests the UN pronouncement and challenges the FONOPS as the US-led strategic move to maintain its strategic primacy and to contain China. The US asserts that it has the right and it will continue its FONOPS drill throughout the world to maintain free navigation principle without meddling by any other country.

The US freedom of navigation is open to the regional allies. Australia is faced with the challenge of positioning itself in the tussle between the US and China. These two big economies have been at odds over the past three years over the status of Chinese 
artificial islands in the South China Sea and U.S. Freedom of Navigation Operations.

On 24 May 2017, Under Trump's Presidency, the first US FONOP took place in which the US sent the guided-missile destroyer USS Dewey to sail through disputed sea, sailing close to Mischief Reef. This also was the first military maritime exercise under Trump presidency (Perlez, 2017). The US asserts that the freedom of navigation means free access to both the exclusive economic zones (EEZ) and territorial seas without permission from the relevant coastal state. But, China is against the military vessels entering a coastal state's territorial seas without official permission. Beijing also claims that military ships in EEZ territorial waters are unlawful and suspicious, and only non-military vessels enjoy the right to passage. For the US, ensuring the freedom of navigation throughout Asia-Pacific region is a national prerogative and a matter of vital importance. As such, China - specifically, its military activities on some of the disputed South China Sea islands - is clearly its main obstacle. So far, no other nations have joined the US FONOPS, and the confrontations have been avoided. But the trend shows that this status quo may not last. According to the Washington-based think tank Center for Strategic and International Studies report: China has completed the major construction work of military infrastructure on artificial islands in the South China Sea and in a position to now set up fighter aircrafts, military assets and missile launchers (Reuters, 2017). Across the region, the nations are concerned about Chinese military incursion and their hope of seeing more American military troops in the region to combat China has not been met. China's building projects continued unabated. China is entering in the space created by recent US inaction in the Indo-Pacific region.

Trump has spoken in recent days with leaders of the Philippines, Singapore and Thailand, inviting each to the White House. Tillerson has tried to reassure allies that freedom-of-navigation patrols will continue. Trump's move to de-emphasize human rights concerns with countries like Thailand and the Philippines could be seen as building bulwark against China, and an obvious move to restrain these countries from falling into China's palm (Hernandez, 2017). The early goodwill between US President Donald Trump 
and China's Xi Jinping has dissipated as differences re-emerge over North Korea, the South China Sea, Taiwan and trade (Dupont, 2017). The security threat is not far for Australia as the long peace is giving way to an intense security and strategic competition between the major powers. Where the US remains the dominant player and the US will have no option but to confront China diplomatically, or militarily. Australia has been avoiding the free navigation drill in joining the US-led military exercises in the Asiapacific region. Australia will have no choice but to take a stand and choose between the US and China if that happens.

\section{Australia-US Alliance is Indispensable: The Strategic Realities}

Critics point towards the blunder decision made by the US in Vietnam War and the Second Iraq War, and Australia's willingness to follow the US in every major war since the inception of its alliance with the US. But, even the closest allies can come to different conclusions. Britain opted out of Washington's Vietnam misadventure, yet their relationship survived and thrived. The alliance with the superpower is an asset for Australia to manage in its national interest. This is a peculiarly unwise moment for Australia to discard a major ally. The Philippines broke off its alliance "The U.S.-Philippines defense agreements" signed in 1952 in 1992, but in 2014 it signed an agreement to allow the US more freedom to operate in its territory (Albert, 2016). Even the great powers, such as Japan, are today reaching to the US for reassurance in the face of Chinese force. No Australians want to see their country in a mindless alliance with America. But the alliance is an advantage for Australia to draw on judiciously, to be neither followed obsequiously nor discarded rashly (Hartcher, 2014).

Though China promotes itself as a new, gentler kind of power, but it's worth remembering that dredging deep water ports and laying down railroad ties to secure new trade routes - and then having to defend them from angry locals - was precisely how Britain started down the slippery slope to empire (Larmer, 2017). China's military build-up is challenging the international system and rule-based order in the Asia-Pacific region. This development is a concern for the all the likeminded democratic nations in the region. The diffusion of liberal economic order, fair play of economic activities, 
and free navigation of good and trade activities are being threatened. In recent years, the South China Sea build-up could be seen in China's unprecedented scale of land reclamation, construction of island airstrips, piers, and surveillance structures and naval modernization has expanded its ability to project power.

Despite all the mixed response from the Trump administration, the official statements are clear that the US would not budge down against China and the US Asia-Pacific policy would involve the burden to be shared its allies as well. Australia has been supportive of most the US- led military operation in the Middle East and the Af-Pak region, but the Australia-US security alliance will be tested in the Asia-Pacific region.

The United States is already having strong strategic and defence alliances in the region with Australia, Japan, South Korea, Taiwan, Singapore, the Philippines and Thailand (Brookings 2016). The US Rebalancing Act has continued under Trump administration and more frequent exercises with likeminded democratic nations in all probability is going to remain a pillar of U.S. foreign policy in the Asia-Pacific region. These alliances are the bedrock of U.S. foreign policy in the region.

The US is paramount to Australia's security and will continue to be a deterring force for prospective adversary and aggressor of Australia. The Australia-US defence ties - commerce, transfer of superior technologies, joint military exercises, joint training and intelligence sharing - have resulted into high level of interoperability and mutual confidence between the armed forces of the both the countries. In addition, Australia's alliance with the world's leading great power provides Australia diplomatic weight in the world.

Despite Australia's economic bonhomie with China, there is divergence between the democratic Australia and an increasingly authoritarian China. The two nations don't go together on the political values and principles. The development in China in the recent years has become more authoritarian and illiberal, reversing the previous trend towards greater pluralism. Not only China's stand on the South China Sea and North Korea but there is 
also a growing concern about the Chinese espionage and cybertheft of Australian intellectual property, the revelations of Chinese influence-buying in Australia and the well-documented pressure on Chinese students and the local Chinese language press to toe Beijing's line have further added to already not so favourable public perception about China in Australia. This is unlike the enduring US-Australia security alliance which is based on shared values and interests.

On the economic front, at first glance one may find that China is ahead of the US as indispensable partner. But argument on the basis of overall trade statistics contradicts this notion. The Australia-US alliance is deep rooted in the similar free liberal and fair economic system. The number shows that Australia-US relationship on this front too is indispensable and the two-way trade goes beyond many would think. Most Australians view China as Australia's most important economic partner. In 2015, Australia- China annual bilateral trade was around $\$ 150$ billion, almost double the Australia-US annual bilateral of $\$ 70$ billion.

This is reflected in Australian foreign minister Julia Bishop repeated reference to the US as "Australia's most important economic partner". Trade is only one component of a broader economic picture. Cumulatively, two-way investment between the US and Australia totals $\$ 1.45$ trillion, dwarfing Australia's other bilateral economic relationships (Holden, Jackman \& Mondschein, 2017). The Australia-US economic relationship is profoundly enrooted in the liberal and market-based values. Secure property rights and procedural fairness - backed by the rule of law and democratic political institutions in both countries - mean that Australia's economic relationship with the US spans access to capital, technological diffusion, and knowledge transfers. In each of these domains, the United States overshadows China, and remains Australia's most important economic partner. The US investments, knowledge transfers and technology have helped fuel Australia's trade surpluses with Asia. Though China too has become an integral economic partner of Australia, but Australia-US economic relationship is dynamic and remains a strong pillar for the prosperity of Australia (Holden, Jackman \& Mondschein, 2017) Additionally, Australia's security alliance with the US reduces not 
only the degree of threat facing Australia but also the defence spending that would otherwise be required to deal with it (DOD, 2015).

Australia is also faced with the challenge of the low-level instability in its neighbourhood, and the impact of fragile states in IndoPacific region, and the Islamic extremism leading to possible terror attacks because of the instability in the Middle East and South Asia. This will continue to pose security challenges to Australia directly or indirectly. These security threats will require international cooperation where Australia will need more and more international collaboration to tackle the conflicts and thwart the possible terror attacks. In this context too the Australia-US alliance is indispensable.

\section{Conclusion}

China's rise is an inevitable phenomenon of this century. The Chinese militarily assertive posture is also leading to the formation of strategic alliances and partnerships to not let China dominate the region. Australia would certainly look for a situation in which it has not to pick between the US and China. The best strategy to pursue its interests for Australia would be to increase its engagement with other powers in the region. There are many developments that are being seen in this context.

One is the emergence of Indo-Pacific region which is the new terminology for the Asia-Pacific region. The Indo-Pacific is a superregion bound by the sea-lanes of communication that carry oil across the Indian Ocean, through the South China Sea and into the Pacific, but also by the ASEAN-centred regional security architecture that has emerged since the 1990s, particularly the East Asia Summit. As such, the concept captures a set of emerging challenges and opportunities to which Australia must respond (Medcalf, 2016). Additionally, the Indo-Pacific term acknowledges the arrival of India and its economic and strategic significance in the context of balance of power in the Indo-Pacific region. 
The trajectory shows that India is all set to one of the top three economic and military powers with a considerable influence in the world and particularly in the Asia-Pacific region in the coming decades. India's "Look East Policy" started in 1990s is now being pursued under the "Act East Policy" by the present Modi Government's multi-alignment policy (Hall, 2016). Some of the major developments in this regards have been India's engagement with Japan, Vietnam, and other China wary countries. It's not only cultural and economic relations that is being emphasised but its security and defence as well. India's deepening comprehensive relationship with the United States of which the growing defence and security relationship is a major component, is being pitched as the defining partnership of the 21st Century with a considerable impact on the balance of power in the 21st century (Sharma 2017).

The Quadrilateral Initiative (Quad), a maritime security agreement between the United States, Japan, Australia, and India (Sharma, 2010), joined by Australia under the Howard Government and then withdrawal under Rudd Government after Australia weighed the option of remaining in the alliance, while running the risk of severing its economic ties with China. However, the idea behind the Quad has resurfaced (Medcalf, 2016), as the United States, Japan, and India have resumed joint naval exercises. Australia has expressed desire to join the Quad if invited (Wroe and Garnaut, 2015). Though the Quad members insist that the Quad is not a military bloc against China, but rather a strategic platform to develop a common thinking on shared security concerns in the Indo-Pacific region, China will nonetheless view the arrangement as a military pact designed to mitigate its attempts to dominate in the Indo-Pacific region.

Independent of the U.S.-backed counter-balance strategy, the U.S. allies and partners are forming defence partnerships amongst themselves in order to maintain the stability in the Indo-Pacific region. This security framework is manifested in Australia's ties with Japan, India's deepening defence relationship with Japan, and the beginning of the Australia-India defence relationship. In its immediate neighbourhood, despite its complex relationship with Indonesia in the past (Brown, Frost \& Sherlock, 195-96), there is a 
great potential for Australia and Indonesia to enhance their security ties.

Australia can escape the reality in which Asia's rivalries drive broader global dynamics, which in turn will pose severe challenges for Australia's regional diplomacy (Griffiths and Wesley, 2010). For Australia a good option would be to shape a balance of power that accommodates China but also favours the region's democracies. But it will be difficult for Australia given China's increasing tilt towards authoritarianism. Australia, while continuing its alliance with US can engage with the democratic powers in maintaining the stability in the Indo-Pacific region. Australia can contribute to this by strengthening its strategic engagement with each of the Asian democracies, with priority given to India, Japan and Indonesia. This can be bilaterally as well as through stronger trilateral arrangements such as Australia-Japan-India, Australia-IndonesiaJapan or Australia-US-Indonesia (Varghese, 2017).

Protecting Australia's border integrity, deterring attacks on Australia, and protecting and promoting Australia's interests in a secured international environment, a range of bilateral, trilateral and quadrilateral security partnership which includes India and Japan as well become more viable in the coming years. As often emphasised in DWPs, Australia will also need to focus on developing a more self-reliant defence policy. But, Australia's alliance with the United States will continue to be relevant and more engaging on the security threat environment in the coming years. Australia relies on the United States for its security, but should the United States is put to a situation to confront Chinese aggression, the U.S.-Australia security alliance will be greatly tested. Australia's alliance with America provides a security guarantee from the world's most powerful military. Australia-US alliance is supported by the public, government and grounded in the strategic realities and the common values for the free and democratic world for which both Australia and the United States stand for. 


\section{References}

ABC News. (2017). Donald Trump's speech to UN General Assembly: The full transcript. 20 September, http:// www.abc.net.au/ news/2017-09-20/donald-trump-speech-to-un-full-transcript/8962616

Albert, E. (2016, October 21). The U.S.-Philippines Defense Alliance: A Backgrounder. Council on foreign Relations. Retrieved from https:// www.cfr.org/ backgrounder/us-philippines-defense-alliance

Australian Embassy in China. (2017). Australia-China Relationship Overview. Retrieved from http://china.embassy.gov.au/bjng/relations1.html

Australian Government. (2013). Strong and Secure: A Strategy for Australia's National Security 2013. Department of Prime Minister and Cabinet. Retreived from http://apo.org.au/ files/ Resource/ dpmc_nationalsecuritystrategy_jan2013.pdf

Brookings. (2016, July 13). Alliances and partnerships: The U.S. Commitments in the Asia-Pacific - A Report. Retrieved from https://www.brookings.edu/research/alliances-partnerships-u-scommitments-in-the-asia-pacific/

Brown, G., Frost, F., \& Sherlock, S. (1996). The Australian-Indonesian Security Agreement: Issues and Implications. Department of the Parliamentary Library. Foreign Affairs, Defence and Trade Group, Research Paper 25. Retrieved from http:// www.aph.gov.au/ About_Parliament/Parliamentary_Departments/Parliamentary_Libra ry/pubs/rp/RP9596/96rp25

Coonan, C. (2016, March 8). China defends right to build in South China Sea as it discovered first. Irish Times. Retrieved from http://www.irishtimes.com/news/world/asia-pacific/chinadefends-right-to-build-in-south-china-sea-as-it-discovered-it-first1.2564540

Department of Defence. (2015). Guarding against Uncertainty: Australian Attitudes to Defence (p.33). Australian Government. Retrieved from http://www.defence.gov.au/whitepaper/docs/GuardingUncertaint y.pdf

Dupont, A. (2017, September 6). Danger ahead for Australia as Asia's long peace ends. The Australian. Retrieved from http:// www.theaustralian.com.au/news/inquirer/danger-ahead-foraustralia-as-asias-long-peace-ends/newsstory/303f1b4173be6b658ccecc5e659fa76e

DWP. (2009). Defending Australia in the Asia-Pacific Century: Force 2030 (Pp. 30-32). Canberra: Commonwealth of Australia. Retrieved from http:/ / 
www.defence.gov.au/whitepaper/2009/docs/defence_white_paper_ 2009.pdf

DWP. (2016). 2016 Defence White Paper. Canberra: Commonwealth of Australia. http://www.defence.gov.au/WhitePaper/Docs/2016Defence -White-Paper.pdf

Fontaine, R. (2016, October 16). Aagainst Ccomplacency: Rrisks and Oopportunities for the Australia-US Alliance. The United States Studies Centre at the University of Sydney. Retrieved from https:// www.ussc.edu.au/analysis/against-complacency-risks-andopportunities-for-the-australia-us-alliance

Forsythe, M. (2017, January 12). Rex Tillerson's South China Sea Remarks Foreshadow Possible Foreign Policy Crisis. The New York Times. Retrieved from https://www.nytimes.com/ 2017/ 01/ 12/ world/ asia/rex-tillerson-south-china-sea-us.html?mcubz=3 “DonaldTrump's speech to UN General Assembly: The full transcript,"

Frazer, M. (2014). Dangerous Allies. Melbourne: Melbourne University Press.

Griffiths, M. and Wesley M. (2010). Taking Asia Seriously. Australian journal of International Affairs, 45(1): 13-28.

Hall, I. (2016). Multi-alignment and Indian Foreign Policy under Narendra Modi. Commonwealth journal of International Affairs, 105(3): 271-286

Hartcher, P. (2014, May 13). Does Australia really need the US alliance?. Sydney Morning Herald. Retrieved from http:// www.smh.com.au/ comment/does-australia-really-need-the-us-alliance-20140512zraey.html

Harvard Kennedy School. (2017). Freedom of Navigation in the South China Sea: A Practical Guide. Belfer Center for Science and International Affair. Retrieved from https://www.belfercenter.org/ publication/ freedom-navigation-south-china-sea-practical-guide

Hernandez, J. C. (2017, May 13). Trump's Mixed Signals on South China Sea Worry Asian Allies. New York Times. Retrieved from https:// www.nytimes.com/2017/05/10/world/asia/trump-south-china-seaallies.html?mcubz=3

Holden R., Jackman S. and Mondschein J. (2017, May 3). By the numbers: How the US is Australia's indispensable trading partner. Financial Review. Retrieved from http://www.afr.com/ news/economy/ trade/by-the-numbers-how-the-us-is-australias-indispensabletrading-partner-20170503-gvxv04

Holmes, A. (2013). Australia's economic relationships with China. Parliament of Australia. Retrieved from http://www.aph.gov.au/ 
About_Parliament/Parliamentary_Departments/Parliamentary_Libra ry/pubs/BriefingBook44p/China

Larmer, B. (2017). What the World's Emptiest International Airport Says About China's Influence. The New York Times Magazine. Retrieved from https://www.nytimes.com/2017/09/13/magazine/what-theworlds-emptiest-international-airport-says-about-chinasinfluence.html?mcubz=3

Malone, P. (2017, May 14). Australia's alliance with the United States mutes our influence in Asia. Sydney Morning Herald. Retrieved from http:/ / www.smh.com.au/federal-politics/politicalopinion/australias-alliance-with-the-united-states-mutes-ourinfluence-in-asia-20170511-gw37kc.html

Medcalf, R. (2016). 'Australia's New Strategic Geography: Making and Sustaining an Indo-Pacific Defence Policy' in Chako P. (ed.) New Regional Geopolitics in the Indo-Pacific: Drivers, Dynamics and Consequences, Abingdon: Routledge.

Medcalf, R. (2016, March 16). The ' $\mathrm{q}$ ' word: US Pacific commander defies diplomatic niceties in New Delhi. The Interpreter. Retrieved from http:/ / www.lowyinterpreter.org/post/2016/03/04/The-q-wordUS-Pacific-commander-defies-diplomatic-niceties-in-New-Delhi.aspx

NIC. (2012). Global Trends 2030: Alternative Worlds. Washington DC: National Intelligence Council Document 2012-001, December, http://www.dni.gov/nic/globaltrends

Paul, T.V. (2005). Soft Balancing in the Age of US Primacy. International Security, 30(1):46-71.

Perlez, J. (2017, May 24). U.S. Warship Sails near Island Claimed by Beijing in South China Sea. New York Times. Retrieved from https:/ / www.nytimes.com/2017/05/24/world/asia/south-china-sea-usnavy-warship-spratly-islands.html?_r=0

Reuters. (2017, March 28). China able to deploy warplanes on artificial islands any time: U.S. think tank. Reuters. Retrieved from http:/ / www.reuters.com/article/us-southchinasea-chinaspratlys/china-able-to-deploy-warplanes-on-artificial-islands-anytime-u-s-think-tank-idUSKBN16Z005

Riordan, P. (2017, August 18). No alternative' to South China Sea exercises, John Howard says. The Australian. Retrieved from http:/ / www.theaustralian.com.au/national-affairs/foreign-affairs/noalternative-to-south-china-sea-exercises-john-howard-says/newsstory/6576c4f46157b3bb1cb0f04cb2f94d77 
SBS News. (2016, January 31). China Condemns US for sending Warships. Retrieved from http:// www.sbs.com.au/ news/ article/ 2016/ 01/ 31/ china-condemns -us-sending-warship

Sharma, A. (2010). Quadrilateral initiative: An Evaluation. South Asian Survey, 17(2), 237-253.

Sharma, A. (2016, June 4). US-Australia Security Alliance. Georgetown Journal of International Affairs.

Sharma, A. (2017). Indian lobbying and its influence in US decision Making: Post-Cold War. New Delhi: Sage Publications.

Thakur, R. (2013). Follow the yellow cake road: balancing Australia's national interests against international anti-nuclear interests. International Affairs, 89(4): 943-961.

USNI News. (2017). A Brief History of U.S. Freedom of Navigation Operations in the South China Sea. 29 May, https:// news.usni.org/ 2017/05/29/ brief-history-us-freedom-navigation-operations-southchina-sea

Varghese, P. (2017). Consider Australia's options if US loses Indo-Pacific clout. The Australian, 18 January, http:// www.theaustralian.com.au/ opinion/consider-australias-options-if-us-loses-indopacific-clout/ news-story/a023bfbec6e82655533fd87e9adabacc

White Paper (2012). Australia in the Asian Century. Australian Government, http://www.defence.gov.au/whitepaper/2013/docs/australia_in_th e_asian_century_white_paper.pdf

Wroe, D. and Garnaut, J. (2015, September 3). Australia flags naval drills with US, India and Japan in signal to China. Sydney Morning Herald. Retrieved from http://www.smh.com.au/federal-politics/politicalnews/australia-flags-naval-drills-with-us-india-and-japan-in-signalto-china-20150903 -gjenvf.html 